\title{
Scrotal Steatocystoma Multıplex
}

Ercüment keskin1*, İbrahim karabulut2, Fatih Özkaya3 „Ragıp İsmail Engin , Sevilay Akalp Özmen, Fevzi Bedir and Fatih Kürşat yilmazel

${ }^{1}$ Regional Training and Research Hospital, Department of Urology, Turkey

${ }^{2}$ Regional Training and Research Hospital, Department of Dermatology, Turkey

${ }^{3}$ Regional Training and Research Hospital, Department of Pathology, Turkey

*Corresponding author: Ercüment Keskin, Department of Urology, Erzincan Üniversitesi mengücekgazi eğitim ve araștırma hastanesi, üroloji anabilim dalı Erzincan,Türkiye

Submission: 㭗January 20, 2018; Published: 佔 March 29, 2018

\section{Introduction}

Steatocystoma Multiplex (SM) is a disease progressing with cysts full of sebum which consists of sebaceous glands on the cyst wall and generally cause multiple lesions [1]. Most of them is seen in the adolescence and young adulthood period. Although autosomal dominant transmission is known, cases without showing familial transmission have been also reported [2]. Lesions are most frequently observed in the neck, axilla, and inguinal region. It is very rare to observe the lesions in scrotum[3]. However, lesions can be seen everywhere having hair follicles including scrotum [4]. We aimed to report a 20-year-old case, who was diagnosed with clinical and histopathological SM and treated, in company with the literature.

\section{Case}

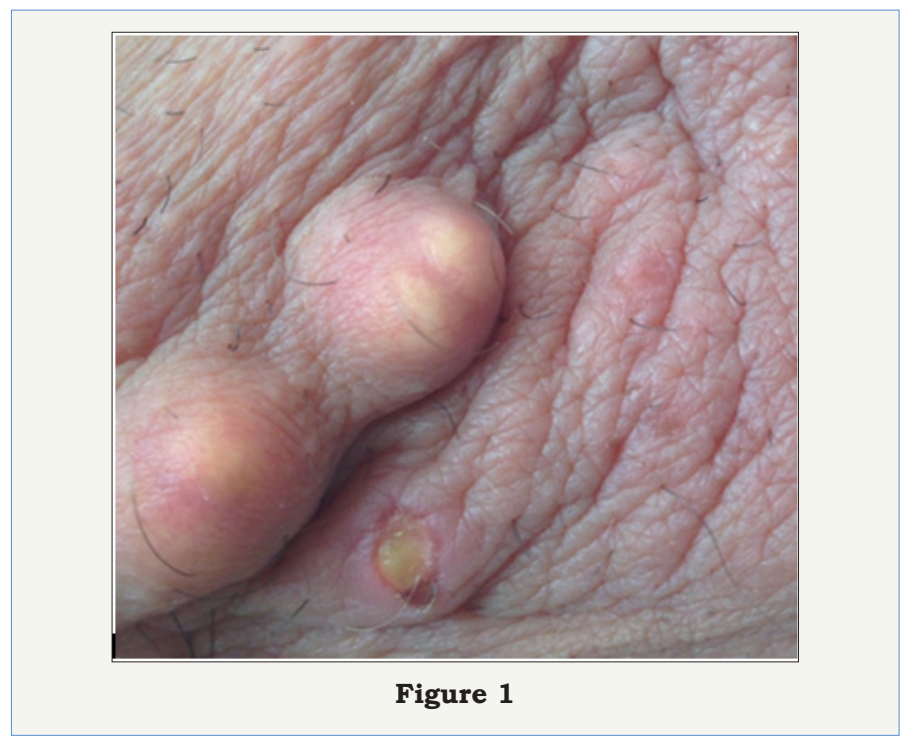

The 20-year-old male patient applied to our polyclinic due to painless small yellow swellings in the scrotal region. The complaint of the patient had started approximately 3 years ago. He specified that size and number of the lesion increased in time. There were no similar lesions in his family. In his physical examination, subcutaneous multiple lesions with sizes varying between 0,5-
$1 \mathrm{~cm}$ were present in the scrotal region (Figure 1). Lesions were characterized by painless yellow cysts with palpation. Other system examination and routine laboratory tests were normal. Lesions disturbing the patient were excised under local anesthesia both for treatment and diagnosis purposes (Figure 2). The patient was diagnosed with SM in the histopathological examination. It was observed in the examination of the patient after fifteen days that the patient had no problem and cystic lesions were completely recovered. In his 2-year follow ups, no relapses and complications were observed.

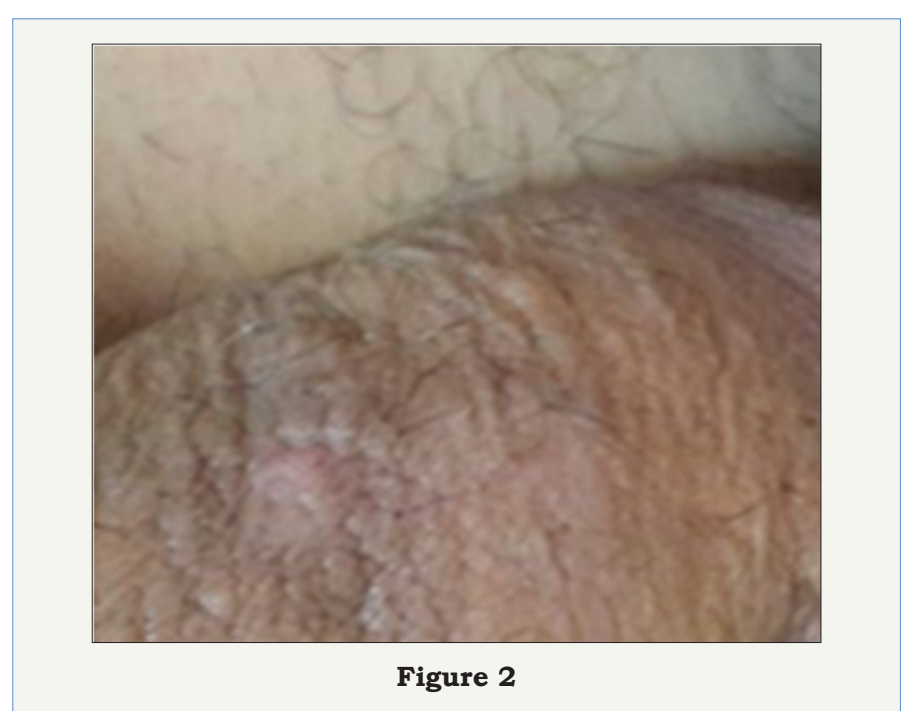

\section{Discussion}

SM is a disease that is generally characterized by numerous, painless and mobile small cystic nodules. Their color is yellowish due to the presence of sebaceous glands [5]. Lesions may vary between 5 and $20 \mathrm{~mm}$. There have been also larger SM cases in the literature. In the study of Rahman et al. [4] a giant SM case was reported that

occupies half of scrotum. Lesions were most frequently observed in the proximal regions of neck, axilla, forefront, abdomen, dorsum, and extremities. They may be observed as spread around various 
areas of the body. The surfaces of the lesions may be calcified and they are generally multiple. They may be yellowish or bluish gray. Cyst may be spontaneously ruptured and show inflammationabscess formation. Lesions generally do not have any symptom except for abscess and inflammation. In our case, lesions were multiple, yellow, painless and located in the scrotum. There was no inflammation finding. The patient applied due to the complaint of cosmetic appearance.

Etiology of SM is not exactly known. Setoyama et al. [6] specified that trauma, infection and immunologic cases may cause SM. Some authors have reported that SM may be associated with ichthyosis and koilonychia, acrokeratosis verruciformis, hypertrophic lichen planus, hypothyroidism, hydradenitis suppurative and hypotrichosis [7]. As in pachyonychia congenita Type II; a relationship with the genes encoding keratin 17 is observed [1]. In our case, no relationship with these skin and systemic diseases was found.

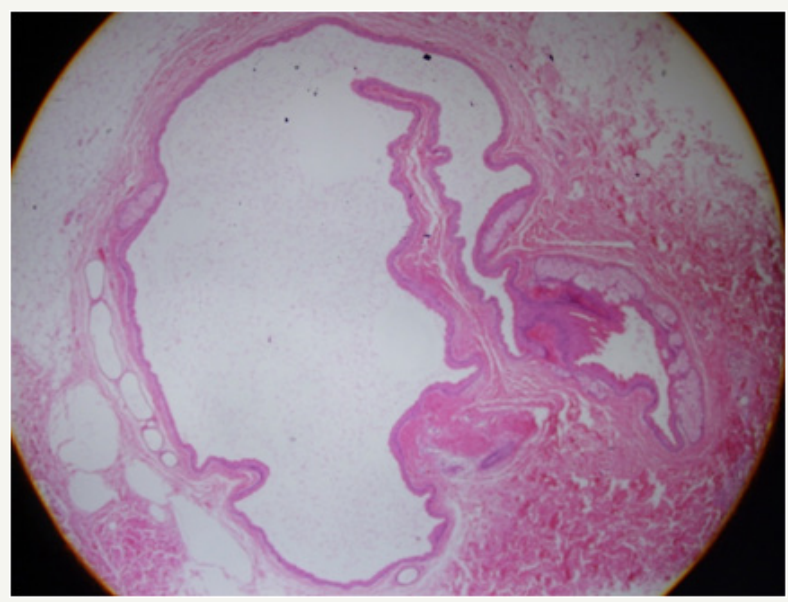

Figure 3: Cystic structures consisting of sebaceous glands on the wall.

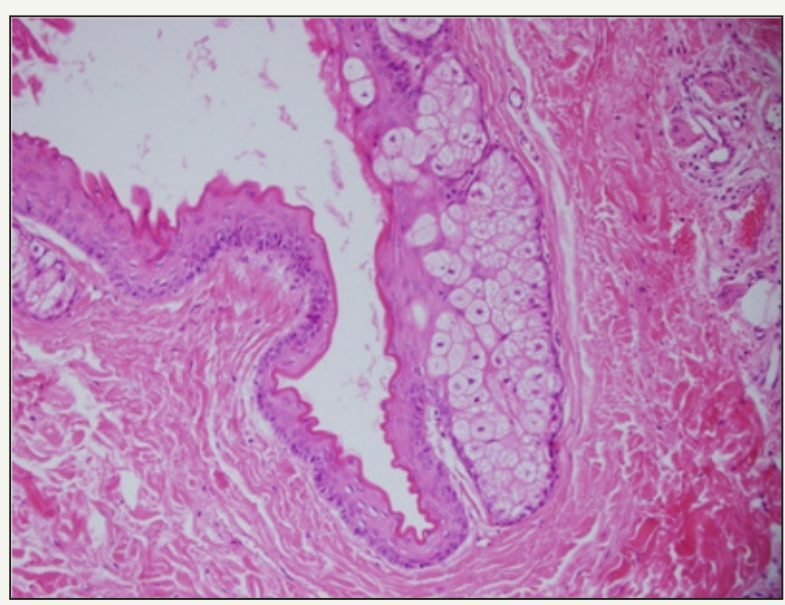

Figure 4: An Eosinophilic keratinous material in its lumen and covered with stratified squamous epithelium and flattened cyst wall.
In differential diagnosis, other cysts such as epidermoid cyst, eruptive vellus hair cyst and also cystic lesions of acne vulgaris and idiopathic scrotal calcification should be considered. Final diagnosis can be made by histopathological examination as a result of biopsy. In histopathological examination, except for the 2-6 sequences of epithelial cells on the cyst wall located on dermis, the presence of sebaceous glands makes us establish the diagnosis of SM. It shows no relationship with epidermis. In the histopathology of the patient clinically diagnosed with SM, cystic structures consisting of sebaceous glands on the wall were reported as an eosinophilic keratinous material in its lumen and covered with stratified squamous epithelium and flattened cyst wall (Figures $3 \& 4$ )

SM does not show malignant transformation [1]. However in time, the number of lesions may increase. Because it generally causes cosmetic problems, its treatment is not compulsory. Even so the definitive treatment of the lesion is surgical excision. However the excess of the cyst number inhibits surgical treatment. In such cases aspiration can be applied in order to reduce number of the lesion[8]. Laser treatment, usage of steroids, and cryotherapy can be beneficial. Even though the excision is the most efficient treatment, undesirable scars can be observed. Lesions showing inflammation should be treated by topical and systemic antibiotics. No recurrence and scar formation was observed in the follow-ups of our case after surgical excision.

As a result, treatment is generally applied due to cosmetic reasons. Mostly surgical excision is preferred for treatment. Subtotal excision of the scrotum wall is a safe treatment method. Final diagnosis is made by histopathological examination.

\section{References}

1. Baykal C (2012) Dermatoloji Atlası. Baskı; İstanbul, Nobel Tıp Kitapevi, Turkey, p. 818.

2. Ebling FJG, Cunliffe W J (1992) Disorders of the sebaceous glands. In: Champion RH, Burton JL, Ebling FJG, (Eds.), Textbook of Dermatology. Blackwell, Oxford, UK, pp. 1699-1744.

3. Anqus W, Mistry R, Floyd MS Jr, Machin DG (2012) Multipl large infected scrotal sebaceous cysts making Fournier's gangrene ina 32-year-old man. BMJ case Rep.

4. Rahman Muhammad Hasibur, Islam MS, Ansari NP (2011) Atypical Steatocystoma Multiplex with Calcification. ISRN Dermatology.

5. Thomas VD, Swanson NA, Lee KK (2008) Benign epithelial tumors, hamartomas, and hyperplasias In: Wolff K, Goldsmith LA, Katz SI, Gilchrest BA, Paller AS, et al. (Eds), Fitzpatrick's Dermatology in General Medicine. McGraw-Hill, (7 $7^{\text {th }}$ edn), New York, USA, pp. 1065-1066.

6. Setoyama M, Mizoguchi S, Usuki K, Kanzaki T (1997) Steatocystoma multiplex: a case with unusual clinical and histological manifestation. The American Journal of Dermatopathology 19(1): 89-92.

7. Marley WM, Buntin DM, Chesney TM (1981) Steatocystoma multiplex limited to the scalp. Archives of Dermatology 117(10): 673-674.

8. James WD, Berger TG, Eliston DM (2006) Andrew's Diseases of Skin, $\left(10^{\text {th }}\right.$ edn $)$ 
Creative Commons Attribution 4.0 International License

For possible submissions Click Here

\section{ETUN} Expermente Urology \&
Nophrology

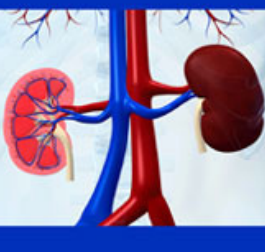

Experimental Techniques in Urology \& Nephrology

\section{Benefits of Publishing with us}

- High-level peer review and editorial services

- Freely accessible online immediately upon publication

- Authors retain the copyright to their work

- Licensing it under a Creative Commons license

- Visibility through different online platforms 